\title{
Improving Gypseous Soil Properties by Using Non-Traditional Additives
}

\author{
Dhay Waddy Mohammed ${ }^{a}$, Balqeea A. Ahmed $^{a}$, Maysam Th. AL-Hadidi ${ }^{b}$ \\ ${ }^{a}$ Department of Civil Engineering, University of Baghdad, Baghdad, Iraq. \\ ${ }^{b}$ Department of Water Resources Engineering, University of Baghdad, Baghdad, Iraq
}

\begin{tabular}{l} 
A R T I C L E I N F O \\
\hline Article history: \\
Received 16 September 2019 \\
Received in revised form 24 October 2019 \\
Accepted 01 November 2019 \\
\hline Keywords: \\
Gypseous Soil \\
Collapsibility \\
Copolymer \\
Permeability \\
Novolac Polymer
\end{tabular}

\begin{abstract}
A B S T R A C T
Gypseous soils are common in several regions in the world including Iraq, where more than $28.6 \%$ of the Iraq surface is covered with this type of soil. This soil, with high gypsum content, causes different problems for construction and strategic projects. As a result of water flow through the soil mass, the permeability and chemical arrangement of these soils varies with time due to the solubility and leaching of gypsum. In this study, the soil of $36 \%$ gypsum content, was taken from one location, which is about $100 \mathrm{~km}$ southwest of Baghdad. The samples were taken from depths of 0.5 and $1 \mathrm{~m}$ below the natural ground and mixed with $3 \%, 6 \%$ and $9 \%$ of Copolymer and Novolac polymer to improve the collapsibility, permeability and compaction parameters. The results of the experimental work showed a noticeable improvement of the collapsibility and permeability of the soil treated with polymer materials compared to the untreated soil. Furthermore, adding $3 \%$ of polymer (copolymer and novolac polymer) materials gave the best improvement in collapsibility which reached a 44.5 and $46 \%$, respectively, in 3 hours. The improvement in permeability reached $98.6 \%$ copolymer and $86.2 \%$ novolac polymer in 1 day.
\end{abstract}

\section{Introduction}

Gypseous soil is considered as one of the most difficult unsaturated soils in the construction of roads and buildings. The presence of the gypsum (Hydrated Calcium Sulphate $\left(\mathrm{CaSO}_{4} \cdot 2 \mathrm{H}_{2} \mathrm{O}\right)$ ) in this soil affects its mechanical and physical properties and makes the soil more sensitive to the water. When water reaches gypseous soil from a heavy rainfall, it causes rearrangement of soil particles, and as a result volume change (decrease) occurs. This change in volume significantly causes a structural failure since the soil loses the bond between the particles and becomes weak to withstand and resist the load applied on it depending on the soil nature and geological structure, the primary soil density, soil structure, the imposed stress, and the amount of wetting [1,2]. In civil engineering the soil can be classified as gypseous soil depending on the amount of gypsum content in it, regardless of soil color or shape. Several researchers indicated that a certain percent of gypsum should exist, such as, $3 \%, 4 \%, 6 \%$ as a lower limit [3].These rates of gypsum have high effects on the physical and mechanical characteristics of soil, and these effects occur unevenly in the soil according

* Corresponding author. Tel.: +964(0)7806898150

E-mail address: dhaekh@yahoo.com (Dhay Mohammeda) 
to the amount of gypsum. To reduce the damage caused to the structure, the gypseous soil should be improved in two ways: mechanical and chemical. The mechanical method is a physical process done by removing and/or adding another soil. The chemical method is made by adding a chemical substance that can change soil properties by means of chemical reactions $[4,5,6]$. It has become necessary to use non-traditional suburb materials to achieve the economic and environmental considerations such as polymers and resins, which are characterized by their effectiveness in a short time. However, there is still rare information about non-traditional suburb materials especially for polymers. However, for economic reasons the chemical composition of polymer is unknown by the companies, which made the researchers looking for its result in improvement rather than on performance mode. Since polymers and resins are not widely used in the past, it has become necessary for many researches to investigate the effect of these additives on the engineering soil properties of gypseous soils.

In 2010, AL-Numani [7] took a soil sample from Najaf that contains $35 \%$ of gypsum and treated it with different rates of cement content (4-8\%). The conducted laboratory tests indicated that increasing the cement content produced an increase in both the optimum water content and maximum dry density to (23.3 and 7.6\%). Vahid and Mohsen [8] used two types of polymer to improve sandy soil and found an increase in compression strength from 0.03 MPa to 5.2 MPa. Al-Neami [9] used (2, 4, and 6\%) clinker additive to treat gypsum soil from Al-Exandria, Babylon, and found that the best clinker ratio was (4\%) which decreased the collapsibility of soil. Fattah and Salman [10] used dynamic compaction method to test three gypseous soil samples with 27, 41.1, and $60.5 \%$ gypsum content. The number of blows used in this study were between 20 and 40. Also, three heights of the drop were used: 35,50 , and $65 \mathrm{~cm}$. The experimental results showed that the best compressibility was obtained when the samples compacted to 20 blows. The results also showed that the dynamic compaction had a greater effect with increased gypsum content. Aldaood and Al-Kiki [11] used samples with 20\% gypsum and improved by $4 \%$ lime and the samples were treated for 2 days. The results showed that when increasing the water velocity through the soil mass, the weight of soil and gypsum are decreased. They noticed a reduction in strength with increasing soaking time. Aldaood and Al-Mukhtar [12] studied the effect of soaking on the mechanical properties of gypseous soil that was treated with $3 \%$ lime and cured for 28 days. It was noticed that a long time soaking had a great effect on the unconfined compressive strength and volume change of the stabilized soil particles. Fattah, et .al. [13] used four samples of gypseous soil with different percentages and treated them by grouting acrylate liquid to reduce the compressibility. The treated samples showed that the acrylate liquid reduced the compressibility of the soil by more than $60-70 \%$ and this behavior may be attributed to the fact that acrylate liquid coated the soil particles, and thus, isolated them from being subjected to the effect of water. The improved samples showed a low collapse potential where acrylate liquid reduced the collapsibility of samples by more than $50-60 \%$ and increased the cohesion of the soil. Majeed et .al. [14] took two sandy clay samples from the AL- Basra Governorate and improved them by the cement of a percentage of 2,4 , and $6 \%$ and by novolac polymer with percentages of $0.2,0.4$, and $0.6 \%$. The test results showed that these ratios were sufficient to obtain a high dry density and increase the strength by 15 and $18.75 \%$ with a duration of less than three hours. However, the addition of $6 \%$ cement and $0.6 \%$ Novolac polymer led to increase the maximum dry density by 2.33 and $3.5 \%$ and the angle of internal friction but reduced the optimum water content. Furthermore, this method reduced the cost by $50 \%$ compared to the method of replacing soil with sand. Ibrahim and Mahmood, [15] took two gypseous soil samples from Baiji and Al-Thurthar and mixed them with 5, 2.5, and $6 \%$ of hydrated lime, hydrated calcium chloride, and kaolin to improve the collapsibility of soil. It was found that the calcium chloride and kaolin achieved the best results while the lime reduced the soil collapsibility to a small degree. Ibrahim and Schanz [16] used a mixture of $30 \%$ of Silber sand and $70 \%$ of Pure Gypsum and treated it with different percentages of silicone oil to improve the engineering properties. The study results showed the silicone oil was able to improve the collapsibility and shear parameters of the gypseous soil. Al- Hadidi and AL-Maamori [17] used gypsum soil samples with $42.55 \%$ gypsum from Karbala city. Different water cement ratios (W/C) were used to decrease the collapsibility of the earth canal and the results showed that $2 \%$ of W/C led to decrease the collapsibility of soil. Vahid and Mohsen [18] took sand samples from Kerman city, Iran, and mixed them with 2, 4, and $6 \%$ of polymer with different periods of treatment ( 3,7 , and 28 days). They found that when the polymer content increased to $6 \%$, the unconfined compressive strength increased by $(66.31 \%)$ in 28 days compared with 3 days. Al-Hadidi. and Ibrahim [19] used 6, 10, and $12 \%$ of polyurethane to reduce the soil erosion of the irrigation canal which was made from gypsum soil in Karbala city with $41 \%$ gypsum. The researchers found the best percentage to use was $10 \%$ which reduced the erosion by $86.2 \%$.

The main goal of this study is to improve the properties of gypsum soil (collapsibility, permeability and compaction parameter) with small quantities and suitable prices by using new non-traditional materials, so the materials that used are copolymer and novolac polymer.

\section{Materials and Experimental Procedure}

\subsection{Materials}

\subsubsection{Gypseous Soil}

To achieve the purpose of study, natural gypseous soil of $36 \%$ gypsum; is taken from one location about $100 \mathrm{~km}$ southwest of Baghdad. The samples were taken from depths $0.5-1 \mathrm{~m}$ below the natural ground surface. The unit weight of the soil in the location was $14.5 \mathrm{kN} / \mathrm{m}^{3}$ and the natural water content $5 \%$. The undisturbed soil samples were air dried, made homogenous, put in plastic bags, and transported to soil mechanics laboratory at civil engineering department, college of engineering at AIQadisiyah University to evaluate the engineering properties of the soil.

\subsubsection{Copolymer}

Copolymer is a mix of non-ionic environmentally safe co-polymer products, where it is considered a new material used for treatment. The material is diluted with water and added to the soil and characterized by the following properties [20]:

- Do not pollute groundwater.

- Safe to plant and animal life in the soil.

- Contains soil moistening agents.

- Good resistance to the Ultraviolet rays.

- Good resistance to erosion.

- Penetrates the soil or any particulate materials.

Table 1. shows the technical properties and form of Copolymers [20]: 
Table 1. The properties of Copolymers

\begin{tabular}{ll}
\hline Element & Style \\
\hline Color & white (transparent once dried) \\
Form & liquid \\
Specific gravity & 1.03 \\
Solid content & $20-22 \%$ \\
Viscosity & $300-350 \mathrm{mPas}$ \\
Surface Tension & $40 \mathrm{mN} / \mathrm{m}$ \\
Freezing point ${ }^{\circ} \mathrm{C}$ & 0 \\
Boiling point ${ }^{\circ} \mathrm{C}$ & 100 \\
pH & 5.5 \\
\hline
\end{tabular}

\subsubsection{Novolac Polymer}

Novolac polymer can be defined as the reaction between phenolformaldehyde and phenol in acid catalyst media and it involves 5 to $6 \%$ of gasoline rings per molecule. The common properties of Novolac polymer are [21]:

1. It has a small molecular weight and it is thermoplastic.

2. Porous arrangement with less mechanical possessions.

3. The curing reaction for the novolac polymer is carried out over $100{ }^{\circ} \mathrm{C}$.

4. It has a density of 1 to $2 \%$ of the density of natural soil and has a color ranging from yellow to orange.

\subsection{Experimental Work}

\subsubsection{Compaction Test}

Standard Procter compaction test was carried out following (ASTM 698) method A [22]. A mold of $10 \mathrm{~cm}$ in diameter and $16.5 \mathrm{~cm}$ in height was used. The samples were compacted in three layers with 25 blows for each layer using a $2.5 \mathrm{~kg}$ hammer which is dropped from $30.5 \mathrm{~cm}$ height and this test was carried out for treated and untreated soils.

\subsubsection{Collapse Test}

Single collapse test was carried out according to the guide proposed by Jennings and Knights [23] and ASTM D5333 [24] on natural compacted and treated gypseous soil samples with various ratios of co-polymer, novolac polymer. The dry weight of specimens was obtained to determine the change in compressibility properties of gypseous soil by using specimens equipped with a ring that was $50 \mathrm{~mm}$ in diameter and $19 \mathrm{~mm}$ in height. The samples were left in the water for 24 hours with a pressure of $200 \mathrm{kPa}$ and then additional static load was applied until it reached $800 \mathrm{kPa}$ then samples were unloaded. The collapse index is obtained from the formula below by using (e-log p) graph under the effect of a certain stress level.

$$
C . P=\frac{\Delta e}{\left(1 \oplus e^{\circ}\right)}
$$

Where:

C.P = Collapse Potential.

$\Delta \mathrm{e}=$ void ratio before and after soaking.

$\mathrm{e}^{\mathrm{o}}=$ Initial voids ratio.

\subsubsection{Permeability Test}

Permeability test was performed for all samples (treated and untreated soil) according to ASTM D-2434 [25]. A mould with $10 \mathrm{~cm}$ in diameter and $13 \mathrm{~cm}$ in height was used. The mould was connected at the top inlet to a water source at a height of $180 \mathrm{~cm}$. The mould had a side outlet at the bottom for the water to flow out of the sample. The quantity of flow for a certain period was collected and recorded. The permeability coefficient was calculated using the equation:

$$
K=\frac{Q}{(A \times I)}
$$

where:

$\mathrm{k}=$ coefficient of permeability.

$\mathrm{Q}=\mathrm{V} / \mathrm{T}$ quantity of water discharged.

$\mathrm{L}=$ the height of the mold.

$\mathrm{A}=$ cross-sectional area of mold

$\mathrm{t}=$ total time of discharge.

$\mathrm{h}=$ the loss of water.

\subsubsection{Physical test}

The specific gravity of the soil is determined according to BS 1377[26], but Kerosene was used instead of water due to the dissolution action of gypsum in water.

The soil was subjected to grain size distribution test according to ASTM D422 [27] to classify the soil. Fig. 1. clearly shows that the soil can be classified as poor grade sand (SP) according to the Unified Soil Classification System (USCS). The engineering and physical properties of the soil are shown in Table 2.

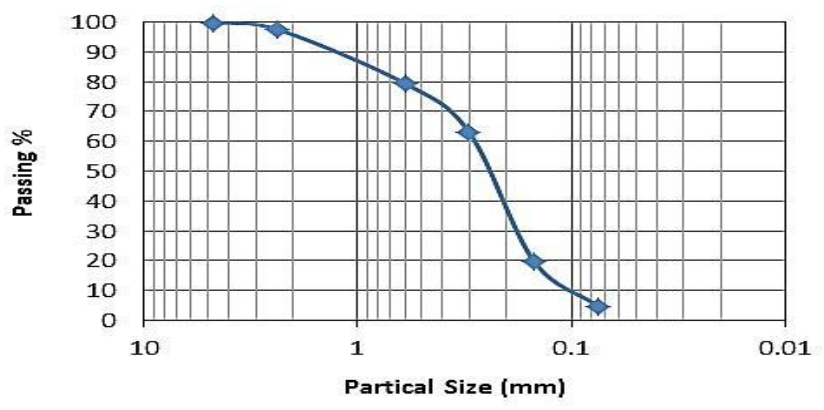

Figure 1. Grain size distribution of gypseous

Table 2. The results of the classification of soil test and physical properties of gypseous soil.

\begin{tabular}{lll}
\hline \multicolumn{1}{c}{ Physical Property } & Value & $\begin{array}{c}\text { Standard of the } \\
\text { test }\end{array}$ \\
\hline \multicolumn{1}{c}{ Maximum Dry Unit Weight } & 16.28 & ASTM, 698 [22] \\
$\begin{array}{l}\gamma_{\mathrm{d}(\max }\left(\mathrm{kN} / \mathrm{m}^{3}\right) \\
\text { Single Collapse }(\%)\end{array}$ & 9.47 & ASTM D5333 [24] \\
Permeability $(\mathrm{cm} / \mathrm{sec})$ & $1.7 \times 10^{-3}$ & ASTM D-2434[25] \\
Specific gravity, GS & 2.54 & B.S1377:1975[26] \\
D10 & 0.1 & ASTM 422[27] \\
D30 & 0.19 & --- \\
D60 & 0.3 & --- \\
Coefficient of curvature, Cc & 1.203 & --- \\
Coefficient of uniformity, Cu & 3 & --- \\
Unified Classification system & SP & --- \\
Optimum Water content Wopt $(\%)$ & 11 & ASTM, 2216[28] \\
\hline
\end{tabular}




\subsection{Chemical Tests}

Several chemical tests were carried out on the soil as shown in Table 3. These tests included:

1. gypsum content which was determined by using the hydration method recommended by Nashat and Al Mufty [29] and S.O.R.B/R6[30]. The hydration method consisted of oven drying the soil sample at $45^{\circ} \mathrm{C}$ until the sample weight became constant. The sample weight at $45^{\circ} \mathrm{C}$ was recorded. After that, the same sample was dried at $110^{\circ} \mathrm{C}$ until the weight became constant and recorded.

The gypsum content was found according to the equation:

$$
X \%=\frac{\left(W 45 c^{\circ}-W 110 c^{\circ}\right) \times 4.778}{W 45 c^{\circ}} \times 100
$$

Where:

$\mathrm{X}=$ gypsum content $(\%)$.

$\mathrm{W} 45^{\circ} \mathrm{C}=$ Weight of the soil sample at $\left(45^{\circ} \mathrm{C}\right)$.

$\mathrm{W} 110^{\circ} \mathrm{C}=$ Weight of the soil sample at $\left(110^{\circ} \mathrm{C}\right)$.

2. Total Sulfate Constant $\left(\mathrm{SO}_{3}\right)$ Test

This test was carried out according to S.O.R.B/R6.In this test natural gypseous soil was used as follows:

1. Take $2 \mathrm{~g}$ of soil and add $200 \mathrm{~g}$ of hydrochloric acid at a concentration of $10 \%$.

2. Heat the sample to boil and filter using filter paper No. 42 .

3. Remove the sample from the heating and add $25 \mathrm{ml}$ of barium chloride with 5\% concentration and leave it for the second day.

4. Filter the sample using filter paper No.54 and wash the precipitate well with hot water until cleaned and place it in a weighted beaker.

5. Put the beaker in the oven to $850^{\circ} \mathrm{C}$ for a quarter of an hour and then leave it to cool and take the weight. $\mathrm{SO}_{3}$ was found according to the equation:

$S O 3 \%=\frac{(W 2-W 1) \times 34.3}{W}$

Where:

W: the weight of the sample.

W1: the weight of the sample after heating.

W2: the weight of the sample after heating.

3.Total Soluble Salts ( T.S.S) Test

T.S.S test was performed according to S.O.R.B/R6 on natural gypseous soil as follows:

1. Take an empty weighted beaker.

2. Place $25 \mathrm{ml}$ of the filtrate sample in the beaker and heat to dry.

3. Remove the sample from heating and leave it to cool and then take the weight again. T.S.S was found according to the equation:

T.S.S $=\frac{(W 1-W 2) \times(10) 6}{V}$

Where:

W1: the weight of beaker before heating.

W2: the weight of beaker after heating.

$\mathrm{V}$ : the volume of filtrate.

4. The X-ray Test
The X-ray tests were carried out on natural gypseous soil identifies the clay and non-clay minerals. These tests were carried out with the assistance of the laboratories of the state company of Geological Surveying and Mining. Results of the X-ray diffraction test are shown in Table 4. and Table 5. shows the details of the test designation.

Table 3. The results of chemical properties tests of gypseous soil

\begin{tabular}{llll}
\hline \multicolumn{1}{c}{ Chemical Property } & Value & Natural value & $\begin{array}{l}\text { Standard of the } \\
\text { test }\end{array}$ \\
\hline Total $\left(\mathrm{SO}_{3} \%\right)$ & 13.87 & $5 \%$ & S.O.R.B/R6 [30] \\
Total soluble salts (T.S.S \%) & 9.8 & Max 10\% & --- \\
Gypsum content (\%) & 36 & Max 10.75\% & --- \\
PH value & 8.21 & $0-14$ & --- \\
O.M (\%) & 0.86 & Max 2\% & B.S 1377-3-1990 \\
& & & \\
\hline
\end{tabular}

Table 4. The results of the X-ray test of gypseous soil

\begin{tabular}{lll}
\hline Element & Wt. \% & Wt. \% sigma \\
\hline $\mathrm{O}$ & 53.46 & 0.3 \\
$\mathrm{Na}$ & 0.56 & 0.07 \\
$\mathrm{Mg}$ & 1.8 & 0.07 \\
$\mathrm{Al}$ & 3.4 & 0.08 \\
$\mathrm{Si}$ & 20.08 & 0.18 \\
$\mathrm{~S}$ & 5.06 & 0.1 \\
$\mathrm{~K}$ & 1.64 & 0.07 \\
$\mathrm{Ca}$ & 11.65 & 0.14 \\
$\mathrm{Ti}$ & 0.13 & 0.06 \\
\hline
\end{tabular}

Table 5. Details of the test designation

\begin{tabular}{ll}
\hline $\begin{array}{l}\text { Test } \\
\text { designation }\end{array}$ & Soil state \\
\hline 0G & Gypseous soil without any added material \\
3GP & Gypseous soil with adding 3\% of Copolymer by weight \\
6GP & Gypseous soil with adding 6\% of Copolymer by weight \\
9GP & Gypseous soil with adding 9\% of Copolymer by weight \\
3GN & Gypseous soil with adding 3\% of Novolac polymer by weight \\
6GN & Gypseous soil with adding 6\% of Novolac polymer by weight \\
9GN & Gypseous soil with adding 9\% of Novolac polymer by weight \\
\hline
\end{tabular}

\section{Analysis and Discussion of the results}

\subsection{Compaction test}

The results of the compaction test are shown below in Fig. 2. and Fig. 3.

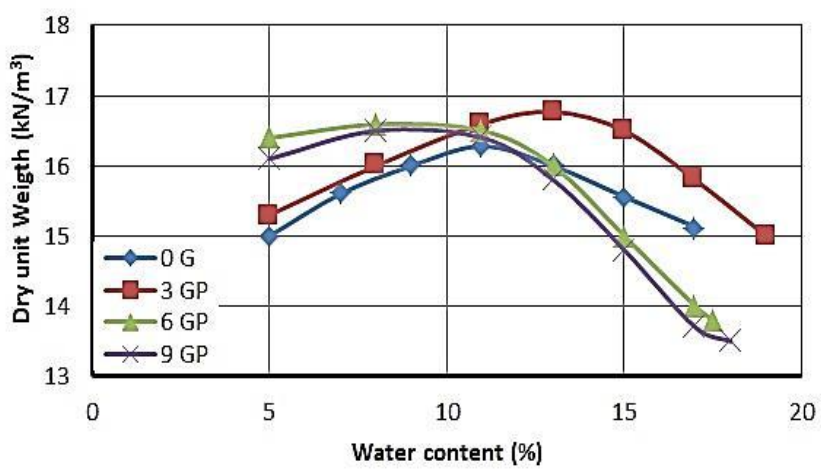

Figure 2. Results of compaction test of gypseous soil treated by different percentage of Copolymer 


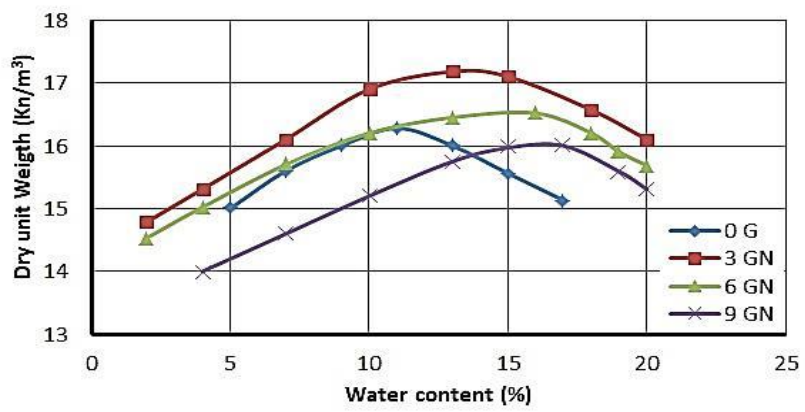

Figure 3. Results of compaction test of gypseous soil treated by different percentage of Novolac polymer

Several observations can be drawn from Fig. 2. and Fig. 3. as illustrated in the following:

1. Little change was observed in the dry unit weight of the improved soil where it increased with increasing the polymer material to $3 \%$. This behaviour may be attributed to the fact that these materials filled the voids between soil particles and had low specific gravity which let them replace some of the soil mass. Subsequently, this led to create a new structure with a large volume and decreased sample weight.

2. The optimum moisture content seemed to stay constant in percentages of $6 \%$ and $9 \%$ of the co-polymers where these materials worked as waterproof while it began to increase with increasing novolac polymer percentage to $9 \%$ where the novolac polymer (solid form) needed more water to attach to the soil particles.

Table 6. The result of compaction test of the gypseous soil treated by copolymer and Novolac polymer

\begin{tabular}{lll}
\hline Materials & $\begin{array}{l}\text { Maximum dry unit } \\
\text { weight }\left(\mathbf{k N} / \mathbf{m}^{\mathbf{3}}\right)\end{array}$ & $\begin{array}{l}\text { Optimum moisture } \\
\text { content }(\boldsymbol{\%})\end{array}$ \\
\hline 0G & 16.28 & 11 \\
3GP & 16.77 & 13 \\
6GP & 16.59 & 8 \\
9GP & 16.51 & 8 \\
3GN & 17.18 & 13 \\
6GN & 16.5 & 16 \\
9GN & 16 & 17 \\
\hline
\end{tabular}

\subsection{Collapse Test}

The samples that were used in this test were compacted to $16.28 \mathrm{kN} / \mathrm{m}^{3}$ maximum unit weight and $11 \%$ optimum water content. As a result of the high gypsum content for natural soil that was used in this research (which is $36 \%$ ), the collapse potential was $9.47 \%$ which was classified as Moderately severe (explained in a drop of the curve for natural soil in Figs 4 and 5) according to the ASTM D5333. The addition of polymer materials caused a reduction in the collapse index depending on the amount of improving materials. Figs $\mathbf{4}$ and $\mathbf{5}$ below shows the results of collapse tests for samples.
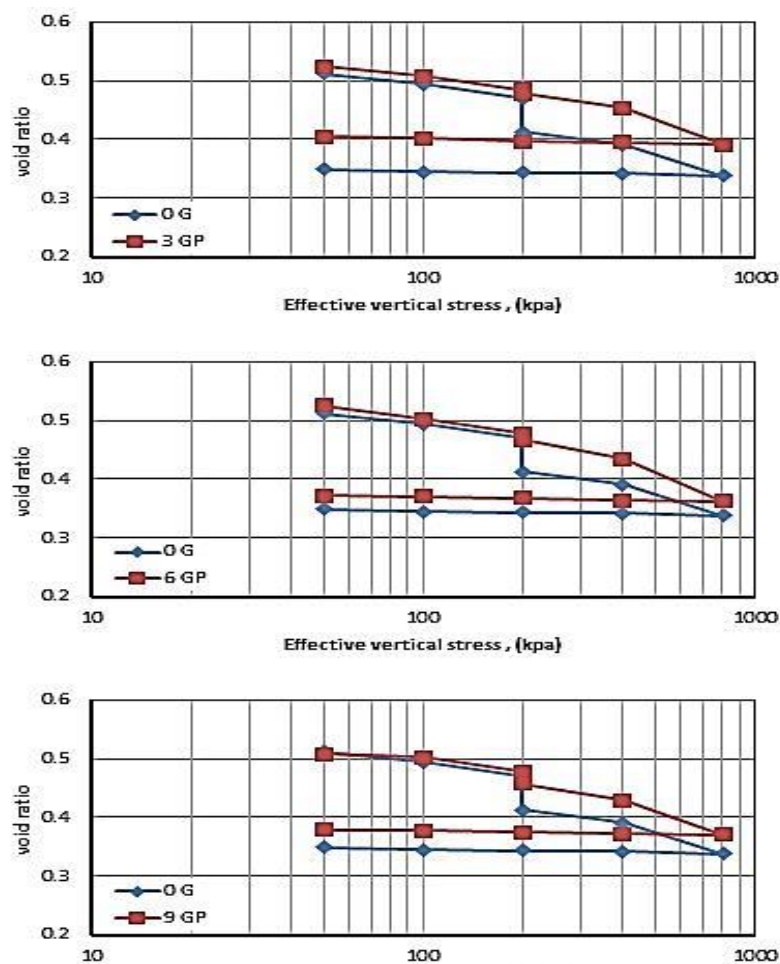

Figure 4. Results of single collapse test of gypseous soil treated by different percentage of Copolymer
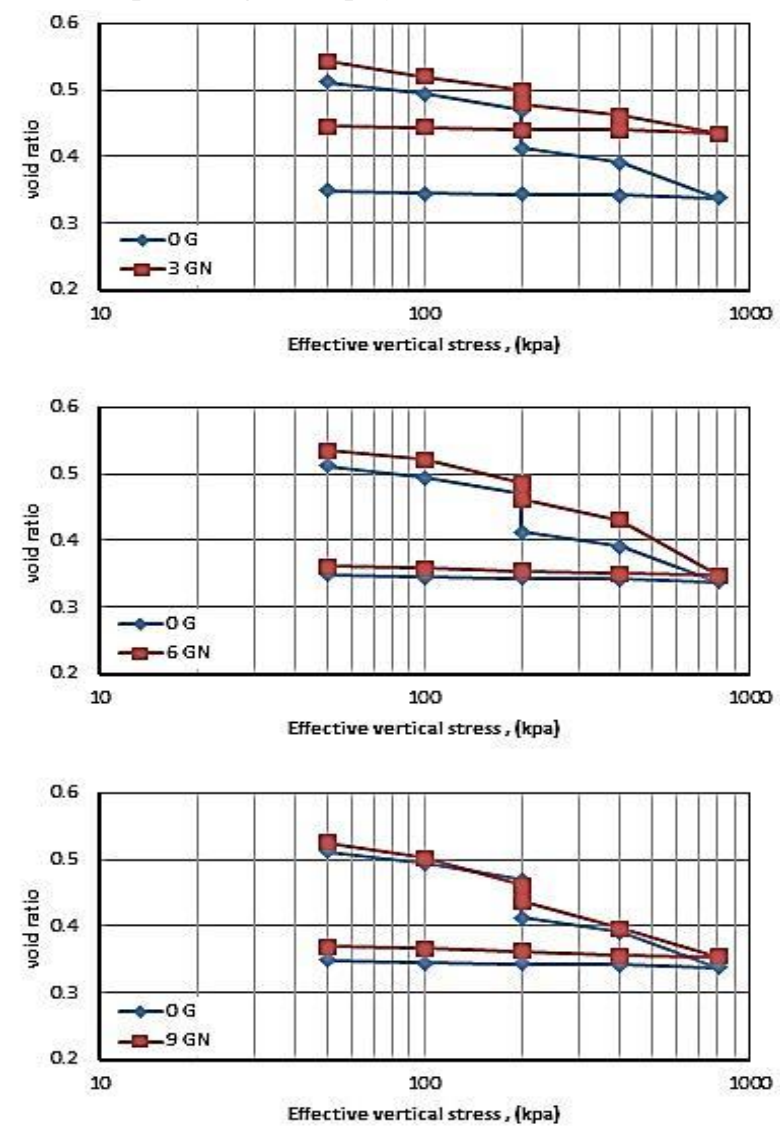

Figure 5. Results of the single collapse test of gypseous soil treated by different percentages of Novolac polymer. 
The collapse index decreased with increasing polymer materials to $3 \%$. This behaviour of soil may be attributed to the fact that these materials covered the soil particles and increased the bonding action between the soil particles. On the other hand, after $3 \%$ polymer content, the polymers made soil particles flocculate and slide causing a drop in soil cohesion. This made the structure of the mass weak and increased the collapse potential, volume of samples, and reduction in dry unit weight. The results are shown in Table 7. and Table 8.

Table 7. The results of a single collapse test before and after improvement

\begin{tabular}{ll}
\hline Materials (\%) & Collapse Index, Ie (\%) \\
\hline 0G & 9.47 \\
3GP & 5.26 \\
6GP & 6 \\
9GP & 6.57 \\
3GN & 5.16 \\
6GN & 6.31 \\
9GN & 7.8 \\
\hline
\end{tabular}

Table 8. The summery of decrease in collapse potential

\begin{tabular}{ll}
\hline Materials (\%) & Improving in Collapse Index, (\%) \\
\hline 3GP & 44.5 \\
$6 \mathrm{GP}$ & 36.6 \\
9GP & 31 \\
3GN & 46 \\
$6 \mathrm{GN}$ & 33.4 \\
9GN & 17 \\
\hline
\end{tabular}

\subsection{Permeability test:}

All the results of the permeability tests are shown in Table 9. In this test the natural and treated soil samples were compacted to the maximum dry unit weight. It was noticed that the soil showed high reduction in the permeability coefficient with the addition of the additive materials. The polymer materials worked as waterproofing, covered the gypsum particles, and filled the voids causing reduction in gypsum dissolution and subsequently the destruction of soil mass structure.

Table 9. Results of permeability test before and after improvement

\begin{tabular}{ll}
\hline Materials $(\%)$ & Coefficient of permeability $(\mathbf{c m} / \mathbf{s e c})$ \\
\hline 0G & $1.7 \times 10^{-3}$ \\
3GP & $1.98 \times 10^{-4}$ \\
$6 \mathrm{GP}$ & $2.3 \times 10^{-5}$ \\
$9 \mathrm{GP}$ & $5.1 \times 10^{-5}$ \\
$3 \mathrm{GN}$ & $5.31 \times 10^{-4}$ \\
$6 \mathrm{GN}$ & $2.35 \times 10^{-4}$ \\
$9 \mathrm{GN}$ & $3.69 \times 10^{-4}$ \\
\hline
\end{tabular}

\section{Conclusions}

1. The maximum dry unit weight increased with adding polymer materials to $3 \%$ and began to decrease after that. Also, clear changes in optimum water content were observed where optimum moisture content decreased to $8 \%$ with increasing the copolymers and increased to $17 \%$ with added the novolac polymer.

2. High reduction in collapse potentials was noticed by increasing the polymer materials to a small amount (3\%) from the copolymer and novolac polymer and the improvement reached to 44.5 and $46 \%$.
3. The coefficient of permeability had lower value with the addition of $6 \%$ of the copolymer and the improvement reached $98.6 \%$, while with adding $6 \%$ of the novolac polymer the improvement reached $86.2 \%$.

4. In terms of cost, these materials are expensive. The basic structure of these materials is oil derivatives and the high price of it is due to the technology used in manufacturing and importing as mentioned before. However, if there is a production factory inside the country that provides such kinds of additives, the cost might be lower or even close to the cement price.

\section{REFERENCE}

[1] Ahmad, F., M.A. Said and L. Najah, (2012): "Effect of Leaching And Gypsum Content On Properties Of Gypseous Soil ", IJSRP, Vol. 2 (9), PP. 1-5.

[2] AYadat, T. and A.M. Hanna, "Encapsulated Stone Column as A Soil Improvement Technique for Collapsible Soil.” Proc., ICE - Ground Improvement, 2005, 9 (4), pp. 137-147.

[3] Al-Emami, O.H., "Collapsibility of gypseous soil under fluc-tuation of groundwater table", M.Sc. Thesis, Building and Construc- tion Department, University of Technology, Iraq, 2007.

[4] Woods "Highway engineering Handbook ' chapter 21, McGraw Hill Book Company, New York, 1960.

[5] Santoni, Rosa L.; Tingle, Jeb S.; Webster, Steve L. "Stabilization of silty sand with non-traditional additives". Transportation research record, 2002, 1787.1 p. 6170.

[6]Tingle, J. S. "Stabilization Mechanisms of Non-traditional Additives," Transportation Research Record: Journal of the Transportation Research Board, 2(1989), 2007, 142-153

[7] AL-Numani, Huda NT." Improvement of the mechanical properties of gypseous soil by additives" Al-Qadisiyah Journal for Engineering Sciences, 3.3: 2010, p.p 383-392.

[8] Zandieh, Ali Reza; Yasrobi, S. Shahaboddin. Retracted article" Study of factors affecting the compressive strength of sandy soil stabilized with polymer". Geotechnical and Geological Engineering, 28.2: (2010), p. 139-145.

[9] Al-Neami, M.A.M, "Improvement Of Gypseous Soil By Clinker Additive" Eng.\& Tech .Journal 2010, Vol 28, No. 19.

[10] Fattah, M.Y., al-Musawi, H.H. and Salman, F.A "Treatment of collapsibility of gypseous soils by dynamic compaction. Geotechnical and Geological Engineering, 30 (6), 2012, p.p.1369-1387.

[11] Aldaood, A., Bouasker, M., Khalil, A.A. and Al-Kiki, I., "Stability Behavior of Lime Stabilized Gypseous Soil. Engineering and Technology Journal, 31(20 Part (A) Engineering), 2013, pp.324-338.

[12] Aldaood, A., Bouasker, M. and Al-Mukhtar, M "Stability Behavior of Lime Stabilized Gypseous Soil under Long-Term Soaking". In IACGE 2013: Challenges and Recent Advances in Geotechnical and Seismic Research and Practices 2013, (pp. 170-177)

[13] FATTAH, Mohammed Y.; AL-ANI, Mohammad M.; AL-LAMY, Mahmoud T. A. Treatment of collapse of gypseous soils by grouting. Proceedings of the Institution of Civil Engineers-Ground Improvement, 2013, 166.1: p.32-43.

[14] Jasim Majeed A., Chyad ,Fatima A; Yaseen, Dina A "Improvement of Selected Parts of Basrah Governorate Soil Using A Mixture of Cement and Novolac polymer", Kufa Journal of Engineering (K.J.E) 2014,5.2 p:61-76.

[15] Ibrahim, S.F., Dalaly, N.K. and Mahmood, G.A.A "Studies on improvement of properties of gypseous soils" Japanese Geotechnical Society Special Publication, 2 (14), (2016) pp.570-575.

[16 ] Ibrahim, A.N. and Schanz, T" Gypseous soil improvement by silicone oil". AlNahrain Journal for Engineering Sciences, 20 (1), (2017) p.p .49-58.17. 
[17] AL- Al-Hadidi, M.T. and AL-Maamori, Z.H.," Improvement of Earth Canals Constructed on a Gypseous Soil By Cement" Association of Arab Universities Journal of Engineering Sciences, 25(5), (2018) pp. 171-189.

[18] Toufigh, Vahid; Rahmannejad, Mohsen. "Influence of Curing Time and Water Content on Unconfined Compressive Strength of Sand Stabilized Using Epoxy Resin". International Journal of Engineering, 2018, 31.8: p. 1187-1195.

[19] Al-Hadidi M. Th. and Ibrahim A. G., " Improvement of Gypsum Soil by Using Polyurethane to Reduce Erosion and Solubility of Irrigation Canals" International Journal of Engineering \& Technology (2018).pp. 372-376.

[20] Web site: www.sbi .com / E-mail:info@sbi-me.com

[21] Gardziella, Arno; Pilato, Louis A.; Knop, Andre. Conclusion: Guidelines for Future Developments in Phenolic Resins and Related Technologies. In: Phenolic Resins. Springer Berlin, Heidelberg, 2000. p. 532-534.

[22] ASTM (D698), "Standard Test Methods for Laboratory Compaction Characteristics of Soil Using Standard Effort $(600 \mathrm{KNm} / \mathrm{m} 3)$ ", Reprinted from the Annual Book of ASTM Standards .Copyright ASTM, 2012, Vol.4, No.8.

[23] Jennings, J. and Knight, K. "A guide to construction on or with materials exhibiting additional settlement due to collapse of grain structure", in 'Proceeding of 6th Regional Conference for Africa on soil mechanics and Foundation Engineering, 1957

[24] ASTM D5333, "Standard Test Method for Measurement of Collapse Potential of Soils", Annual Book of ASTM Standards, Vol.04.08, Philadelphia, PA, ASTM,
USA. Copyright, ASTM International, 100 Barr Harbor Drive, PO Box C700, West Conshohocken, United States 2003.P19428-2959.

[25] American Society of Testing and Materials (ASTM),."Standard Test Method for permeability of Granular Soils (constant Head) ASTM D2434-68 ,West Conshohocken, Pennsylvania, USA ,2006.

[26] BS 1377 - 2 (British Standard Institution), "Method of test for soils for civil engineering purposes" British Standard Institution, London, UK. , 1990.

[27] American Society for Testing and Materials (ASTM), "Standard test method for particle size analysis of soils ", ASTM D422 International, West Conshohocken, Pennsylvania, USA, 2002.

[28] ASTM, D 2216 Standard test methods for laboratory determination of water (moisture) content of soil and rock by mass. West Conshohocken: American Society for Testing \& Materials, 2005.

[29] Al-Mufty, A.A .and Nashat, I.H, "Gypsum content determination in Gypseous soils and rocks", 3rd International Jordanian Conference on Mining , (2000) pp,500-506.

[30] SORB/R6 "Iraqi Standards for Roads and Bridges" General Organization for Roads and Bridges, Baghdad, Iraq, 1983,

[31] British Standard Institution, 1990, Methods of test for soils for civil engineering purposes. BS 1377-1990: Part 1, 2, and 3, London, 133 p. 